Jpn. J. Med. Mycol.

Vol. 43, 153-160, 2002

ISSN $0916-4804$

総説

\title{
Aspergillus 感染成立に関与する好中球の役割
}

\author{
鈴 木 和 男 \\ 国立感染症研究所・生物活性物質部
}

\begin{abstract}
要旨
真菌感染は，好中球機能低下による日和見感染と深くかかわっていることが明らかになってきている．好中球のも つ lysosome 酵素の myeloperoxidase（MPO）と活性酸素産生酵素 NADPH oxidaseの欠損した患者の好中球機能の 解析や，こ机ら遺伝子のノックアウトマウスを用いたin vivoの感染実験の解析から，ラジカル酸素産生能の低下が真 菌感染抵抗性の低下をもたらしていることが解明された. MPO酵素欠損患者では Candida albicans の感染抵抗が低下 していることが欧米で報告されている，さらに，われわれが作製した MPO 遺伝子ノックアウトマウスによるin vivoの感染尖験からも一義的にC. albicansへの感染抵抗が低下していることが判明している. 一方, NADPH oxidase 欠損は，慢性肉芽腫症（CGD）となって重篤化する疾患で, Aspergillus 感染への抵抗性が極度に低下していることが 特徵である. NADPH oxidase は, 膜蛋白質 cytochrome b558 と細胞質蛋白質 p47phox, p67phox, p40phox 等の分子群から なり，好中球の活性化によって，これら分子が膜に集合してユニットとなって活性を発現する．また，真菌の慢性的 な感染は，血管炎やアレルギーの誘発にもつながっている。
\end{abstract}

Key words: myeloperoxidase (MPO), NADPH oxidase, 欠損症 (deficiency), ノックアウトマウス (knockout mouse), Candida albicans, Aspergillus, 慢性肉芽腫症 (chronic granulomatous disease: CGD)

\section{1. 真菌感染と日和見感染}

真菌感染は, 好中球機能低下による日和見感染と泾く かかわっていることが明らかになってきている．最近， 真菌感染には, 好中球のもつ lysosome 酵素の myeloperoxidase（MPO） と活性酸素産生酵素 NADPH oxidase の 2 つの酵素が極めて重要な役割を担っていることが解 明されてきている，本稿では，この 2 つの酵素と真菌感 染防御との関倸を中心に述べる。

\section{2. 真菌感染の防御における好中球の役割}

好中球は，生体防御機能の初期にはたらき，殺菌，殺 ウイルス，殺真菌，殺腫瘍細胞など自然免疫（innate immunity）の重要な機能を担っている. 好中球系の防 御細胞は, 系統発生でみても昆虫や軟体動物にも存在し ており，単細胞のアメーバの機能に似ている，好中球は 細胞膜が柔軟で，細胞内骨格が発達し，すばやい反応性 を示す．刺激や反応に対応してアメーバ様の運動性を示 す。その動きは，感染防御の先端での監視役として，異 物に対してすばやい反応が必要であり，その反応と連動 によって，異物を捕食（貪食，phagocytosis）し，消化す るといった一連のダイナミックな機構全般に不可欠な要 素として備わっている。しかし，殺真菌機構の解析はほ とんどされていないのが現状である.

别刷請求先：鈴木 和男

T 162-8640 新宿区戸山 1-23-1

国立感染症研究所・生物活性物質部
Metchinicoff の食細胞の発見から 100 年を経過し，好 中球は, 感染防御のマーカー, 炎症細胞のマーカーとし ての古典的研究から, 好中球走化性因子の発見や細胞内 情報伝達機構に始まる分子生物学の研究によって, 好中 球の機構解析と臨床応用の研究へと目覚しく発展し, 好 中球は様々な機能面をもつことが明らかにされた ${ }^{1-5)}$. な かでも，リセプター・リガンドの反応から異物認識・粘 着にはじまる細胞内情報伝達の解析は, 細胞内情報伝達 機構の解析研究のさきがけ的なものになった6-11). その 様な背景から，他の免疫細胞には顕著に現れない非特異 的障害性を有するのも好中球の特徵である. 好中球の基 本的な機能について述べ，ついで，真菌感染抵抗にどの ように作用するかについて述べる.

\section{3. 好中球固有の細胞機能}

好中球を細胞の機能面から見ると, 粘着, 遊走（走化 能) (Fig. 1), 貪食, 脱顆粒 (酵素放出能), 殺菌の機能 を持ち，それぞれ順次ステップを追って生体防御機能の 役割を担っている。 これらの機能について, 個々述べる.

\section{1 ) 粘着機能}

好中球は，末梢血液を循環している時は，血管の内皮 細胞に粘着しないが, 一旦, 感染, 炎症などの刺激によっ て活性化されると血管内皮細胞に粘着し，ローリングし ながら血管内皮細胞をすりぬけるとされている12). しか し，最近，好中球が内皮細胞の外を通るのではなく，内 皮細胞が好中球を取り込み（吞み込み），血管外へと移 動する（放出する）といった報告もある ${ }^{13)}$.このステッ 
プは，好中球が生体防御細胞としてはたらく際の重要な 第一歩である.この粘着という好中球機能は, 血管内皮
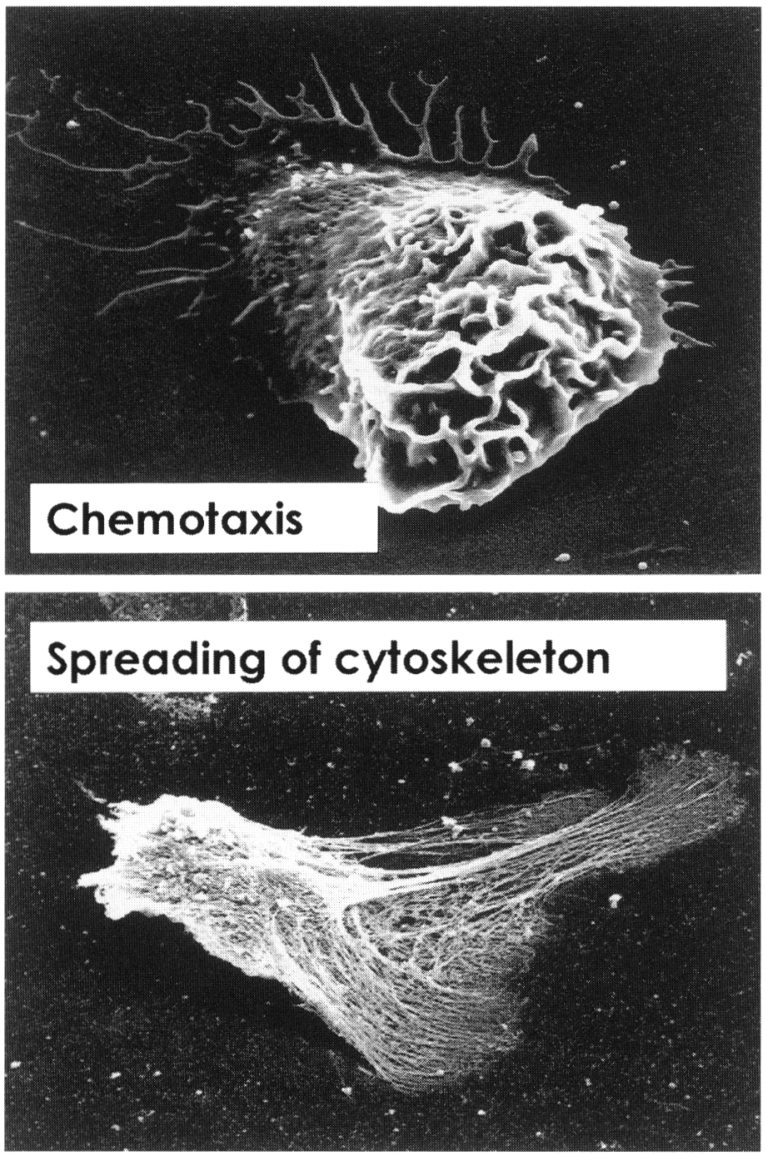

Fig. 1. Chemotaxis and spreading of cytoskeleton of human neutrophils Scanning electronic microscope. (photo by Ms. N. Saito in National Institute of Infectious Diseases)
細胞への粘着のみではなく，その他の好中球機能の全般 にわたって重要な役割に関与している.

2 ) 遊走・走化能

血管から外へ出た好中球は, 感染部位や炎症部位へと 移動する。この機能のうち細胞の移動機能を「遊走」と いう。一方，感染部位や炎症部位へと方向性をもって遊 走することを「走化性」という。この走化性は，方向性 をもった遊走であるので，移動先の方向をキャッチする 必要がある，好中球が方向をキャッチするには，局所か らの情報を得る必要があり, 好中球は, 局所から産生さ

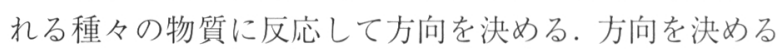
因子には, 補体成分 $\mathrm{C} 5 \mathrm{a}$, 細菌産生ペプチド fMet-LeuPhe (FMLP)，ロイコトリエン B4，インターロイキン 8, LECT 2 などが走化性因子として明らかにされてい る14-19)。また，これらの因子によって，好中球が活性化 される。これらの走化性因子のリガンドと結合する好中 球表面のレセプターにある補体成分 C5a レセプター, FMLP レセプター，ロイコトリエン B4レセプター，イ ンターロイキン 8 レプターなどがクローニングされて いる20-22)。これらのレセプターと結合することで好中球 細胞内へと情報が伝達され，好中球が活性化される。こ の情報伝達に呼応して好中球の膜の流動性が上昇する。 遊走や走化性には, 膜の流動性が不可欠である。しかし， 真菌感染に招ける遊走にかかわる因子などについては不 明である。

3 ) 食機能（貪食作用）

感染部位へ好中球が到達すると，そこに増殖している 細菌・ウイルスを即座に食べる23-26)。この現象を「食作 用」あるいは「領食」と呼んでいる。好中球が生体防御 機能を発揮するには, 細菌, ウイルスを細胞内に貪食し

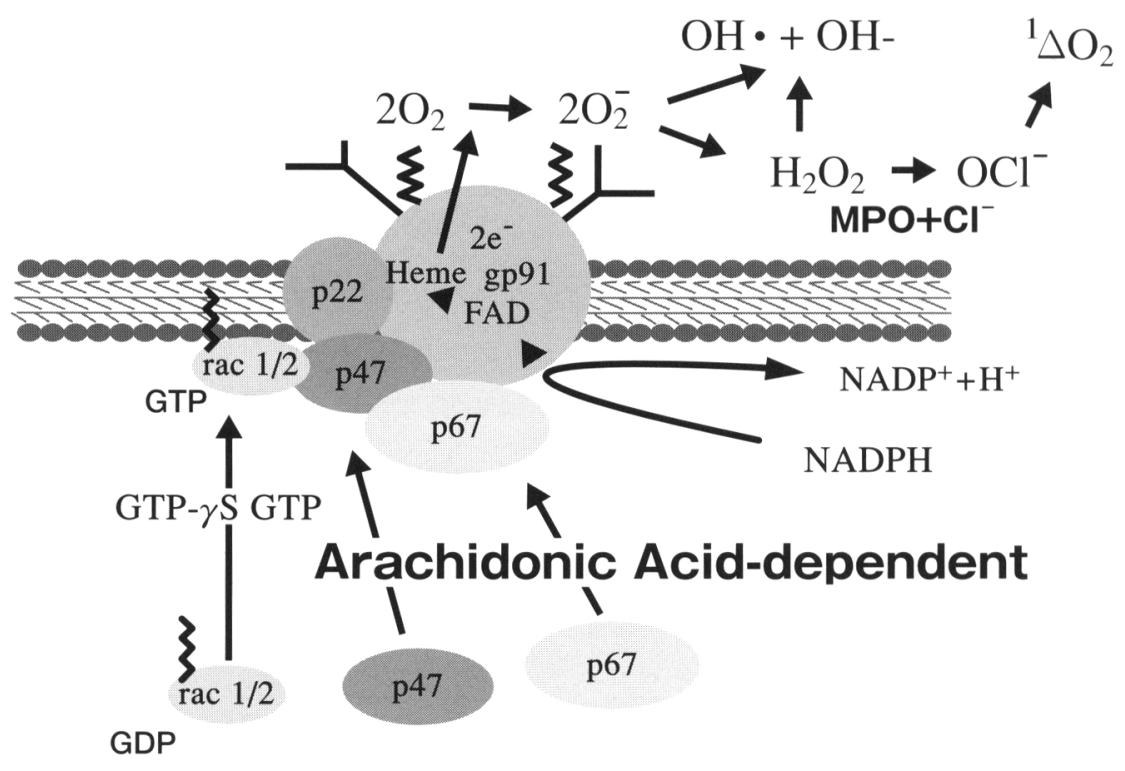

Fig. 2. A scheme for activation of NADPH oxidase in stimulated neutrophils. (drawn by Prof. H. Nunoi in Department of Pediatrics, Miyazaki Medical School) 


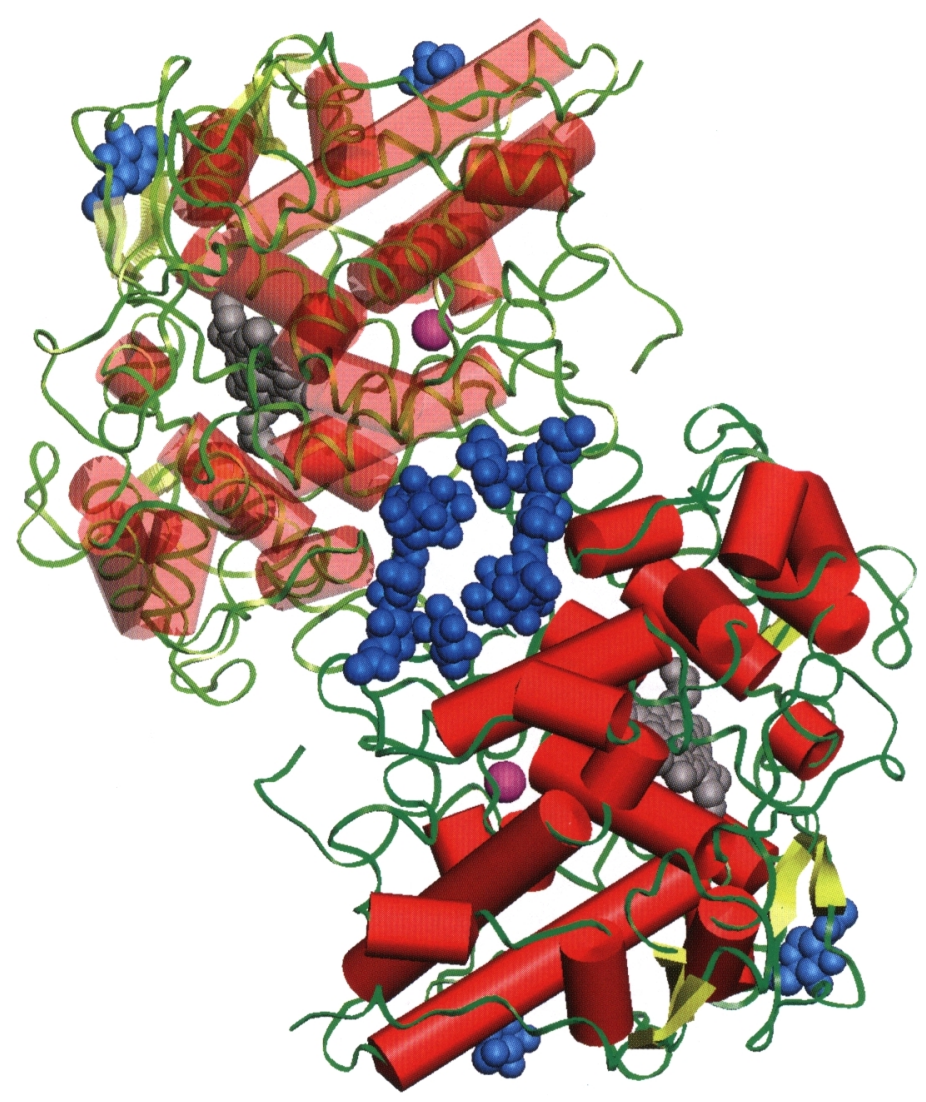

Fig. 3. 3D structure of MPO molecule. Simulation drawn by Dr. R. Suzuki, Marine Biotechnology Institute and Prof. M. Tanokura, Graduate School of Agriculture and Life Sciences, University of Tokyo.

て物理的に封じ込め，細菌・ウイルスの生体内での増殖 を抑制することで役割を果たしている。この機能にも好 中球の粘着機構と膜の流動性が関与している。すなわち, 特異的レセプターを利用した接着と非特異的な接着には じまる貪食機能である、貪食しながら，細菌・ウイルス などを食胞（phagosomes）に閉じ込める。この反応は， かなり機敏で秒から分単位での反応である。しかし，真 菌の場合は, 食機能 (貪食)によって真菌を食胞に閉じ 込めている像は観察されておらず，どのような機構で殺 作用を示すかを調べる必要があるだろう。

4 ) 脱顆粒・酵素放出と活性酸素産生

好中球は, 細菌を貪食後, 細菌およびウイルスを不活 性化し, また, 真菌も不活性化する24-26), あるいは殺す ことが生体防御での主たる役割である。好中球は，貪食 して食胞をつくるやいなや好中球内の顆粒（ライソゾー ムを含む 4 種の顆粒）と融合してファゴライソゾームを 形成する. そして, 顆粒内の消化・不活化酵素をそのファ ゴライソゾームの中に放出する。これと同時に，活性酸 素も産生し, 殺細菌, 殺ウイルス・殺真菌をする。リガ ンドと結合した好中球は，その情報を蛋白質りん酸化な どを通じて，細胞内に瞬時に伝達する。その典型的なも のが活性酸素産生や脱顆粒・酵素放出する一連の細胞内 情報伝達経路である。

以上のように，好中球は，生体防御機能として，活性 化されてから殺菌するまでの機能を有し，かつ，活性化
が即時におこる。

\section{5 ）活性酸素産生と MPO 放出}

5-1) 活性酸素産生系

NADPH oxidase は，膜蛋白質 cytochrome $b_{558}$ （gp91 $1^{\text {phox }}$ と $\mathrm{p} 22^{\text {phox }}$ のサブユニット）と細胞質蛋白質 $\mathrm{p} 47^{\text {phox }}, \mathrm{p} 67^{\text {phox }}, \mathrm{p} 40^{\text {phox }}$ 他の分子群から構成される. 好中球の活性化によって，これら分子が膜に集合してユ ニットとなって活性を発現する (Fig. 2). NADPH oxidase を構成しているこれらの各 phox 分子は, 異なっ た遺伝子にコードされ，その遺伝子の変異，欠損や発現 異常がCGDをもたらす.また, phox 分子群および MPO の遺伝子発現は, コードされている遺伝子の異常のみな らず，遺伝子発現調節部位で調節している転写因子の機 能不全によっても phox 分子群の遺伝子発現の異常をも たらし，好中球機能不全を引き起こす，その結果，Aspergillus や Candida の感染を許して臨床症状にあらわれる.

5-2) MPO 分子.

MPO は, light chain $(14 \mathrm{kDa})$ と heavy chain $(59 \mathrm{kDa})$ の 2 分子に heme 2 分子をもつ $158 \mathrm{kDa}$ のヘテロテトラ マーの糖たんぱく質で (Fig. 3), 等電点 10.3 以上で第 17 染色体にコードされている. $\mathrm{NaCl}$ と $\mathrm{H}_{2} \mathrm{O}_{2}$ を基質とし て $\mathrm{OCl}^{-}$を産生する (Fig. 4).これらの不全症は真菌 症に重要であることが判明している。また，コードされ ている遺伝子特にへム結合部位の異常や転写因子の機能 不全によって MPO 分子の異常をもたらし, 主にCandida 


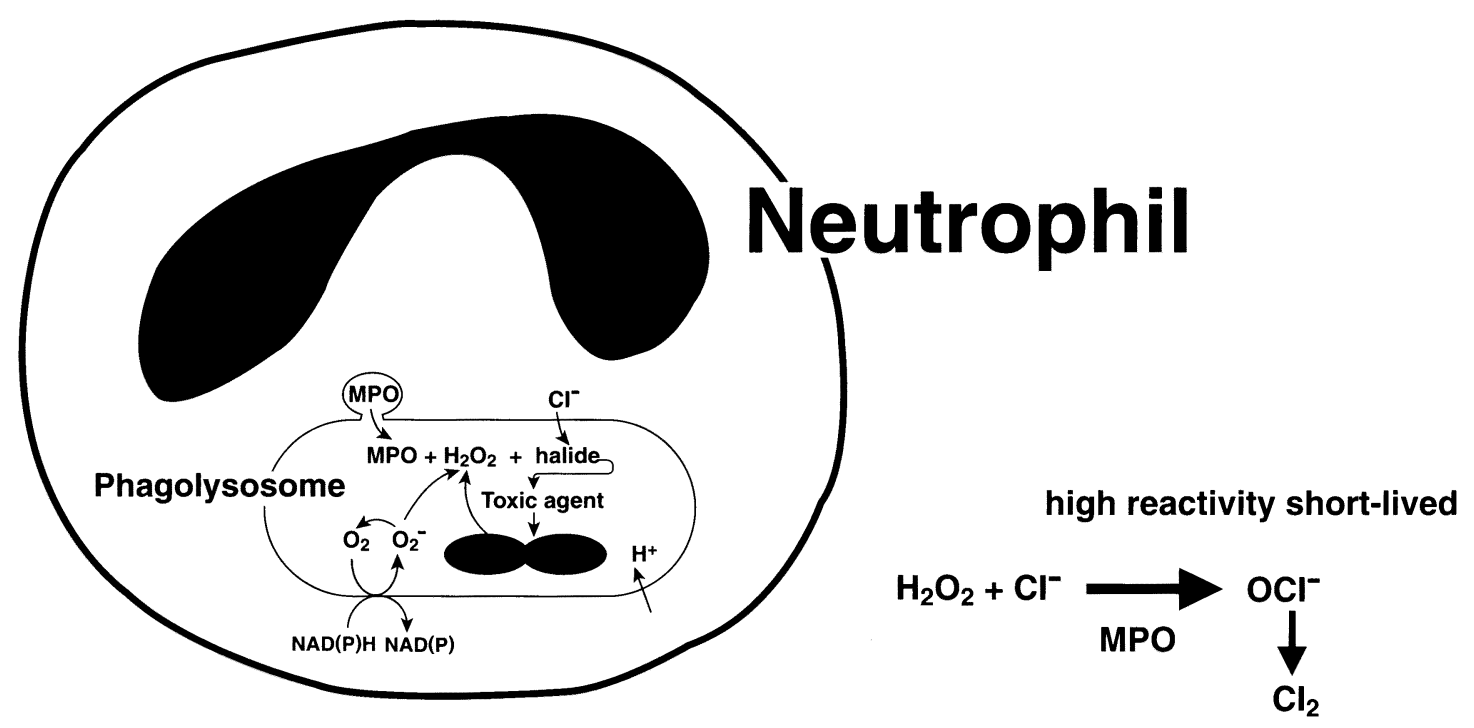

Products of chloride oxidation by MPO and $\mathrm{H}_{2} \mathrm{O}_{2}$

Fig. 4. $\mathrm{OCl}^{-}$production catalyzed with $\mathrm{MPO}$ released from neutrophils. The released MPO into phagolysosome catalyzes $\mathrm{H}_{2} \mathrm{O}_{2}$ and $\mathrm{NaCl}$ to produce $\mathrm{OCl}^{-}$.

の感染症を誘発する.

\section{4. 真菌の不活性化機構とその不全}

好中球が真菌を頜食するには，真菌は大きく，実験的 にも報告がない，癌細胞を傷害するのと同様に好中球が 産生する活性酸素や MPO あるいは顆粒内分子を放出し て真菌表面の分子を変性させて, 機能を不活性化するも のと推定される. 実験的には, MPO が産生する $\mathrm{OCl}^{-}$ によって Candidaの表面分子が剥離されやすいことや $\mathrm{O}_{2}{ }^{-}$が Aspergillus の増殖を抑制していることなどからも 予想される.しかし, その詳細な機構は判明していない.

これまで，NADPH oxidase およびMPOを欠損した 患者の好中球機能の解析や, これら遺伝子のノックアウ トマウスを用いたin vivoの感染実験の解析から，ラジ カル酸素産生能の低下が真菌感染抵抗性の低下をもたら していることが解明されてきている. NADPH oxidase 欠損は, Aspergillus 感染を主とした真菌感染を誘発し, CGDとなって重篤化すること, および, NADPH oxidase (gp91 ${ }^{\text {phox }}$ ) 久損マウスの解析から, NADPH oxidase は, Aspergillus 感染への抵抗性に極めて重要であることが判 明している.また, Aspergillus 感染は, 単純に $\mathrm{O}_{2}{ }^{-}$産生不 全だけではなく，その下流に位置する $\mathrm{H}_{2} \mathrm{O}_{2}$ も産生され ないことから $\mathrm{CGD}$ は, $\mathrm{O}_{2}{ }^{-}$と $\mathrm{OCl}^{-}$の両者の産生不全 が原因となって重篤になると思われる. 事実われわれは, gp91phox と MPO それぞれのノックアウトおよびこれら のダブルノックアウトマウスから解析して証明した ${ }^{27)}$.

一方, MPOは, NADPH oxidase から派生する $\mathrm{H}_{2} \mathrm{O}_{2}$ を基質として $\mathrm{Cl}^{-}$と反応して $\mathrm{OCl}^{-}$を産生し, 殺細菌, 殺ウイルスすることが in vitroで明らかにされている. しかし，MPO酵素欠損においては細菌の易感染傾向に ついては報告がほとんどなく，本邦の欠損例でもそのよ
うな症状は報告されていない。しかし，欧米での MPO 酵素欠損患者では Candida albicans 感染抵抗が低下し ていることが報告されている. MPO 遺伝子ノックアウ トマウスによるin vivoの感染実験からも一義的にC . albicans の感染抵抗が低下していることが判明してい る28,29)ことから, MPO は,一義的に, C. albicans をはじ めとする抗真菌として働いていることが証明されている.

\section{5. 真菌感染に誘発される慢性炎症}

\section{1 ）好中球活性化による血管傷害}

好中球の生体防御という一義的な機能が，ややもする と，条件・状況によって生体側に不利な細胞傷害を引き 起こして炎症を惹起する．感染によって MPOは，血液 中に放出され，CRPと同様に炎症がおさまると同時に， クリアされる。これは，好中球の活性化状態と関連して おり，川崎病や腎炎患者などの血管炎患者の血中には， 高 MPO 活性とともに, 活性化好中球が循環しているこ とが，好中球の機能の解析から明らかになっている30,31). この活性化好中球は，続発する炎症や感染によって血管 傷害の誘発に関与すると推定されている. Fc $\gamma$ レセプター 欠損マウスでは，腎炎が発症せず，好中球の活性化が関 与していることが示されている.

2 ) 好中球の活性化に関与する好中球自己抗体 ANCA 活性化好中球は, 真菌感染の防御に加えて, 血管炎の 発症と病態の進行に関与していると推定されている. マ ウスでは, 好中球の Fc $\gamma$ レセプターを介して発症する ことがそのノックアウトマウスを使って示されているこ とから，自己抗体 MPO-ANCA 抗体が好中球を活性化 していると予想される ${ }^{32)}$. 血管炎の臨床像から，好中球 が生体側に不利な細胞傷害を引き起こすには, ANCA が関与しており, 特に, MPO-ANCAの関与について解 
析が進んでいる。この抗体の対応分子は，殺菌，殺真菌， 殺ウイルス作用に作用する好中球に固有のライソゾーム 酵素の MPOである. 血管炎の患者の血中には, 高 MPO 活性值につづいて活性化好中球および高レベルの MPOANCA 抗体が循環している。これは，川崎病や腎炎患者 好中球の機能の解析から明らかになっている. なかでも 活性化好中球は，一次的な感染によって血管傷害の増悪 化誘発に関与すると推定されており，MPO-ANCA 抗体 の性状と活性化好中球が，どのように血管炎の発症と病 態の進行への関与をしているか今後注目される.

2-1) 好中球ライソゾーム酵素 MPO 抗体 MPO-ANCA の血清マーカーとしての利用

MPO-ANCA は，血管炎を呈する疾患にその上昇が認 められる疾患の臨休マーカーとして利用されている好中 球細胞質抗体である ${ }^{33-35)}$. 本抗体の対応分子の MPO は, $\mathrm{H}_{2} \mathrm{O}_{2}$ を基質として細胞傷害を示す酵素である。血清中 の MPO-ANCA 陽性の対象疾患として，川崎病や腎炎 などの血管炎が主であるが，慢性関節リウマチや SLE においても MPO-ANCA が高值を示すケースがある.

2-2) MPO-ANCA とその対応抗原の病因性

これら疾患患者の血清中の MPO-ANCAの抗体価だ けでは，必ずしも疾患の病態と連動していないことがわ かっており，病態と密接に関与するMPO-ANCA は，そ の抗原・抗体必応と, それにつづく免疫複合体によって， 好中球が活性化され，その状態が持続することによって， 病態の重篤化を招くのではないかと考えられている.

\section{2-3) MPO-ANCA エピトープの解析の必要性}

病態と関連したMPO-ANCAの関与について解析す るためには，抗体による MPO 分子との反応部位（エピ トープ）を特定することと, 反応性・血管傷害に関わる 抗体を特定することが重要である。また，好中球を活性 化する抗体の性状と病態に連動する好中球の活性化との 関係を特定することも重要である，そこで，血管炎の病 態を判定するための MPO-ANCA エピトープ解析用パ ネルが作成された。このセットを使った MPO-ANCA エピトープ解析用 ELISA 法を用いて，血管炎関連患者 血清の MPO-ANCA 抗体のエピトープ解析から, MPO の $\mathrm{L}$ 鎖とは全く反応せず，主として $\mathrm{H}$ 鎖の $\mathrm{N}$ および $\mathrm{C}$ 末端に単独で反応するエピトープをもつ MPO-ANCA 抗体が重症化と関連していた36,37)。この解析結果は, 特 定のモノクローナル抗体が重症化と関連していると予想 された. 以上から，クロナリテイは血管炎疾患抢よび病 態と関連があることを示唆している.

2-4) MPO-ANCA クローンと好中球活性化による血 管炎進行

エピトープ解析から MPO-ANCA のモノクローナル 抗体が血管炎の進行と関わることがわかった. また, Fc $\gamma$ レセプター欠損マウスでは，腎炎が発症しないことから， 好中球の活性化に関与する抗体抢よび免疫複合体は特異 性が高いモノクローナル抗体であることが見えてくる. 一方, 川崎病の治療に用いられているグロブリン製剤は, MPO-ANCA を含んでいるが，ポリクローナルであるこ
とが判明している。健常者血中にも MPO-ANCA が含 まれているのと同様である。これらのことから，病因性 の高いモノクローナル抗体が，ポリクローナルによって 弱められていることが治療に有効性を示す一因である可 能性もある.

2-5 ) 真菌誘発の血管炎モデルマウス

真菌誘発の血管炎の治療や, 病因の解析に重要なのが, モデルマウスである。その一つに，Candida albicans extract 誘発の冠状動脈炎マウス ${ }^{38)}$ がある.このマウス は，血管炎発症とともに，血中にMPO-ANCA が上昇す る. MPO 遺伝子欠損マウスでは, 血管炎の発症と共に MPO-ANCA が低下することから，MPOが主たる抗原 になって，血管炎の発症に関与していることが明らかに なっている39).

\section{3 ) Aspergillus 誘導の喘息アレルギーなどの慢性炎症 性アレルギー}

真菌症によって誘発される慢性炎症のアレルギーがあ り，特に，Aspergillus 誘導の喘息アレルギーの研究が進 展している. なかでも, 呼吸器への慢性的な真菌感染に よって喘息などが誘発される. その誘発に関与するアレ ルゲンの研究として，その成分のリコンビナントを作製 して投与する実験結果が報告されている. 囊胞性肺線症 (cystic fibrosis) 患者の不可逆的な肺のダメージを誘発 する病因を解析するために,リコンビナント抗原 (rAspf) を投与し，肺ダメージとの関係を調べた. 55 人の患者 のテストで, 21 人が Aspergillus fumigatus アレルギーで, 12 人がアレルギー性肺気管アスペルギロシス（ABPA） に罹患していた。この患者は，2つの細胞質アレルゲン (rAspf4 [30-kD たんぱく質で, 機能不明]および rAspf6 [23-kD Mn-SOD: $\left.10^{-2} \mu \mathrm{g} / \mathrm{ml}\right]$ の 1 つにすくなくとも 反応した40)。このようにアレルゲンを特定しようという 試みも進んでいる。ささに, 分子生物学的解析により Aspergillus fumigatus のたんぱく質 SS 結合イソメラーゼ ファミリー遺伝子の関与も指摘されている41). また，好 中球の関与も調べられている ${ }^{42)}$. 一方, 真菌誘発の喘息 動物モデルの研究も発展してきている. 動物喘息モデル では，IL-18 および Toll-like receptor-2が，慢性真菌誘 発の喘息にかかわっている43). また, Aspergillus fumigatus の conidia 誘導のマウスモデル慢性喘息発症には, マス 卜細胞や IL-5 刺激の好酸球に発現する CXCR2が不可 欠であることを，そのノックアウトマウスを用いて解析 している ${ }^{44)}$. Aspergillus fumigatus の conidia をチャレン ジすることで, 喘息アレルギーなどの呼吸器障害がおこ るがその原因が IL-13にあり, Stat6 は直接関与しない45). この様に, 発症機構の解析とともに, 治療の試みもモデ ルマウスによって調べられはじめた．抗原の刺激により 極めて高いIgEを呈するABPAに似たモデルができ， 末梢および肺での好酸球が非常に増加し, 肺炎, 気道機 能直進がみられる.このモデルを使ったワクチンの開発 もここ数年進んできており，このモデルマウスを使った 治療へむけた研究が今後は多くなるだろう46). 
本執筆にあたり，アドバイスいただきました直江史郎 先生, 高橋啓先生, 渋谷和俊先生, 大原関利章先生（以 上，東邦大 - 医 - 大橋病院)，大野尚仁先生 (東京薬大), 岡崎富男先生（広島市民病院）, 荒谷康昭先生（横浜市 大・木原生物研）ならびに当室大川原明子博士に感謝い たします。

\section{文献}

1) Clark RA, Klebanoff SJ: Neutrophil-mediated tumor cell cytotoxicity: role of the peroxidase system. J Exp Med 141: 1442-1447, 1975.

2) Klebanoff SJ: Oxygen metabolism and the toxic properties of phagocytes. Ann Intern Med 93: 480-489, 1980.

3) Lehrer RI, Cline MJ: Leukocyte myeloperoxidase deficiency and desseminated candidiasis: the role of myeloperoxidase in resistance to Candida infection. J Clin Invest 48: 1478-1488, 1969.

4) Sepe SM, Clark RA: Oxidant membrane injury by the neutrophil myeloperoxidase system. I Characterization of a liposome model and injury by myeloperoxidase, hydrogen peroxide, and halide. J Immunol 134: 1888-1895, 1985.

5) Nauseef WM, Cogley M, Bock S, Petrides PE: Pattern of inheritance in hereditary myeloperoxidase deficiency associated with R569W missense mutation. J Leuk Biol 63: 264-269, 1998

6) Borregaard N, Heiple JM, Simons ER, Clark RA: Subcellular localization of the b-cytochrome component of the human neutrophil microbicidal oxidase. Translocation during activation. J Cell Biol 97: 52-61, 1983.

7) Clark RA, Malech HL, Gallin JI, Nunoi H, Volpp BD, Pearson DW, Nauseef WM, Curnutte JT: Genetic variants of chronic granulomatous disease: prevalence of deficiencies of two discrete cytosolic components of the NADPH oxidase system. N Engl J Med 321: 647 652, 1989.

8) Volpp BD, Nauseef WM, Donelson JE, Moser DR, Clark RA: Cloning of the cDNA and functional expression of the $47 \mathrm{kDa}$ cytosolic component of the human neutrophil respiratory burst oxidase. PNAS $\mathbf{8 6}$ 7195-7199, 1989.

9) Clark RA, Volpp BD, Leidal KG, Nauseef WM: Two cytosolic components of the human neutrophil respiratory burst oxidase translocate to the plasma membrane during cell activation. J Clin Invest 85: 714$721,1990$.

10) Leto TL, Lomax KJ, Volpp BD, Nunoi H, Sechler JMG, Nauseef WM, Clark RA, Gallin JI, Malech HL: Cloning of a $67 \mathrm{kDa}$ neutrophil cytosolic oxidase factor and its similarity to a non-catalytic region of p60c-src. Science 248: 727-730, 1990.

11) Reumaux D, Vossebeld PJ, Ross D, Vewhoeven AJ: Effect of tumor necrosis factor-induced integrin activation on Fc gamma receptor II-mediated signal transduction: relevance for activation of neutrophils by anti-proteinase 3 or anti-myeloperoxidase antibodies. Blood 86: 3189-3195, 1995.

12) Catalina MD, Estess $P$, Siegelman MH: Selective requirements for leukocyte adhesion molecules in models of acute and chronic cutaneous inflammation: participation of E- and P- but not L-selectin. Blood 93: 580-589, 1999.

13) Hoshi O, Ushiki $T$ : Scanning electron microscopic studies on the route of neutrophil extravasation in the mouse after exposure to the chemotactic peptide $\mathrm{N}$ formyl-methionyl-leucyl-phenylalanine (fMLP). Arch Histol Cytol 62: 253-260, 1999.

14) Smith RJ, Wierenga W, Iden SS: Characteristics of $\mathrm{N}$-formyl-methionyl-leucyl-phenylalanine as an inducer of lysosomal enzyme release from human neutrophils. Inflammation 4: 73-88, 1980.

15) Gerard C, Bao L, Orozco O, Pearson M, Kunz D, Gerard NP: Structural diversity in the extracellular faces of peptidergic G-protein-coupled receptors. Molecular cloning of the mouse $\mathrm{C} 5 \mathrm{a}$ anaphylatoxin receptor. J Immunol 149: 2600-2606, 1992.

16) Yokomizo $T$, Izumi $T$, Chang $K$, Takuwa $Y$, Shimizu T: A G-protein-coupled receptor for leukotriene B4 that mediates chemotaxis. Nature 387: 620-624, 1997.

17) Matsushima $\mathrm{K}$, Morishita $\mathrm{K}$, Yoshimura $\mathrm{T}$, Lavu $\mathrm{S}$, Kobayashi Y, Lew W, Appella E, Kung HF, Leonard EJ, Oppenheim JJ: Molecular cloning of a human monocyte-derived neutrophil chemotactic factor (MDNCF) and the induction of MDNCF mRNA by interleukin 1 and tumor necrosis factor. J Exp Med 167: 1883-1893, 1988.

18) Suzuki K, Miyasaka H, Ota H, Yamakawa Y, Tagawa M, Kuramoto A, Mizuno S: Purification and partial primary sequence of a chemotactic protein for polymorphonuclear leukocytes derived from human lung giant cell carcinoma LU65C cells. J Exp Med 169: 1895-1901, 1989.

19) Yamagoe S, Yamakawa $Y$, Matsuo $Y$, Minowada J, Mizuno S, Suzuki K: Purification and primary amino acid sequence of a novel neutrophil chemotactic factor LECT2. Immunol Lett 52: 9-13, 1996.

20) Gao JL, Chen H, Filie JD, Kozak CA, Murphy PM: Differential expansion of the $\mathrm{N}$-formylpeptide receptor gene cluster in human and mouse. Genomics 5: 270276, 1998.

21) Prossnitz ER, Ye RD: The N-formyl peptide receptor: a model for the study of chemoattractant receptor structure and function. Pharmacol Ther 74: 73-102. 1997.

22) Junger WG, Hoyt DB, Davis RE, Herdon-Remelius C, Namiki S, Junger $\mathrm{H}$, Loomis $\mathrm{W}$, Altman A: Hypertonicity regulates the function of human neutrophils by modulating chemoattractant receptor signaling and activating mitogen-activated protein kinase p38. J Clin Invest 101: 2768-2779, 1998.

23) Klebanoff SJ: Myeloperoxidase-occurrence and biological function. In Peroxidase in Chemistry and Biology (Everse J, Grisham M eds), p.180-192, CRC Press, Boca Raton, 1990.

24) Yamamoto K, Miyoshi-Koshio T, Utuki Y, Mizuno S, Suzuki K: Virucidal activity and viral protein modification by myeloperoxidase: A candidate for defense factor of human polymorphonuclear leukocytes against influenza infection. J Infec Dis 164: 8-14, 
1991.

25) Klebanoff SJ, Coobes RW: Viricidal effect of polymorphonuclear leukocytes on human immunodeficiency virus-1: role of the myeloperoxidase system. J Clin Invest 89: 2014-2017, 1992.

26) Nguyen C, Katner HP: Myeloperoxidase deficiency manifesting as pustular candidal dermatitis. Clin Infest Dis 24: 258- , 1997.

27) Aratani $Y$, Kura F, Watanabe H, Akagawa H, Takano, Y, Suzuki K, Dinauer MC, Maeda N, Koyama H: Critical role of myeloperoxidase and NADPH-oxidase in high-burden systemic infection of mice with Candida albicans. J Infect Dis, in press.

28) Aratani Y, Koyama M, Nyui S, Suzuki K, Kura F, Maeda N: Severe impairement in early host defense against Candida albicans in mice deficient in myeloperoxidase. Infection and Immunity 67: 1828-1836, 1999.

29) Aratani Y, Kura F, Watanabe H, Akagawa H, Takano Y, Suzuki K, Maeda N, Koyama M: Differential host susceptibility to pulmonary infections with bacteria and fungi in mice deficient in myeloperoxidase. J Infectious Diseases 182: 1276-1279, 2000.

30) Okazaki T, Sakatani T, Sasagawa S, Ota H, Onishi $\mathrm{H}$, Suzuki $\mathrm{K}$ : Enzyme release and $\mathrm{O}_{2}{ }^{-}$production of neutrophis and vascular lesions in gamma globulin therapy of kawasaki disease. Progress in clinical and biological research 250: Kawasaki Disease (Shulman S. T. Alan R. ed), p.557-558, Liss Inc, New York. 1987.

31) Minoshima S, Arimura $Y$, Nakabayashi K, Kitamoto K, Nagasawa T, Ishida-Okawara A, Suzuki K: Increased release of myeloperoxidase in vitro from neutrophils of patients with myelopreoxidase-specific anti-neutrophil cytoplasmic antibody (MPO-ANCA) related glomerulonephritis. Nephrology 3: 527-534, 1997.

32) Falk RJ, Jennette JC: Antineutrophil cytoplasmic autoantibodies with specificity for myeloperoxidase in patients with sytemic vasculitis and idiopathic necrotizing and crescentic glomerulonephritis. N Engl J Med 318: 1651-1657, 1988.

33) Arimura $Y$, Minoshima S, Kamiya Y, Nakabayashi K, Kitamoto K, Nagasawa T, Sasaki T, Suzuki K: Serum myeloperoxidase and serum cytokines in a anti-myeloperoxidase antibody associated glomerulonephritis. Clin Nephrol 40: 256-264, 1993.

34) Saeki $T$, Kuroda $T$, Morita $T$, Suzuki K, Arakawa M, Kawasaki K: Significance of myeloperoxidase in rapidly progressive glomerulonephritis. Am J Kidney Dis 26: 13-21, 1995.

35) Saeki $T$, Kuroda $T$, Morita $T$, Suzuki K, Arakawa $\mathrm{M}$, Kawasaki K: Significance of myeloperoxidase in rapidly progressive glomerulonephritis. Am J Kidney Dis 26: 13-21, 1995.

36) Gilligan HM, Bredy B, Bredy HR, Hebert M-J, Slayter HS, Xu Y, Rauch J, Shia MA, Koh JS, Levine JS: Antineutrophil cytoplasmic autoantibodies interact with primary granule constituents on the surface of apoptotic neutrophils in the absence of neutrophil priming. J Exp Med 184: 2231-2241, 1996.

37) Tomizawa K, Mine E, Fujii A, Y-Ohashi Y, Yamagoe $\mathrm{S}$, Ishida-Okawara A, Hashimoto Y, Ito M, Tanokura M, Yamamoto T, Arimura Y, Nagasawa T, Mizuno S, Suzuki K: A panel set for epitope analysis of myeloperoxidase (MPO)-specific anti-neutrophil cytoplasmic antibody MPO-ANCA using recombinant hexamer histidine-tagged MPO Deletion Mutants. J Clin Immunol 18: 142-152, 1998.

38) Fujii A, Tomizawa K, Arimura $Y$, Nagasawa T, YOhashi Y, Hiyama T, Mizuno S, Suzuki K: Epitope analysis of myeloperoxidase-specific anti-neutrophil cytoplasmic antibody (MPO-ANCA) associated glomerulonephritis. Clin Nephrol 53: 242-252, 2000.

39) Murata H, Iijima $H$, Naoe $S$, Atobe $T$, Uchiyama $T$, Arakawa S: The pathogenesis of experimental arteritis induced by Candida alkali-extract in mice. Jan J Exp Med 57: 305-313, 1987.

40) Ishida-Okawara A, Oharaseki T, Takahashi K, Hashimoto Y, Aratani Y, Koyama H, Maeda N, Naoe $\mathrm{S}$, Suzuki K: Contribution of myeloperoxidase to coronary artery vasculitis associated with MPO-ANCA production. Inflammation 25: 381-387, 2001.

41) Nikolaizik WH, Weichel M, Blaser $K$, Crameri R: Intracutaneous tests with recombinant allergens in cystic fibrosis patients with allergic bronchopulmonary aspergillosis and Aspergillus allergy. Am J Respir Crit Care Med 165: 916-921, 2002.

42) Nigama S, Sarmab PVGK, Ghoshc PC, Usha Sarmaa P: Characterization of Aspergillus fumigatus protein disulfide isomerase family gene. Gene 281: 143-150, 2001.

43) Little SA, MacLeod KJ, Chalmers GW, Love JG, McSharry C, Thomson NC: Association of forced expiratory volume with disease duration and sputum neutrophils in chronic asthma. Am J Med 112: 446452, 2002.

44) Blease K, Kunkel SL, Hogaboam CM: IL-18 modulates chronic fungal asthma in a murine model; putative involvement of Toll-like receptor-2. Inflammation Research 50: 552-560, 2001.

45) Schuh JM, Blease K, Hogaboam CM: CXCR 2 Is necessary for the development and persistence of chronic fungal asthma in mice. J Immunology 168: 1447-1456, 2002.

46) Blease K, Schuh JM, Jakubzick C, Lukacs NW, Kunkel SL, Joshi BH, Puri RK, Kaplan MH, Hogaboam CM: Stat6-deficient mice develop airway hyperresponsiveness and peribronchial fibrosis during chronic fungal asthma. Am J Pathol 160: 491-490, 2002.

47) Kurup VP, Grunig G: Animal models of allergic bronchopulmonary aspergillosis. Mycopathol 153: 165177, 2002. 


\title{
Contribution of Neutrophils to Aspergillus Infection
}

\author{
Kazuo Suzuki \\ Dept. of Bioactive Molecules NIID-NIH, Tokyo
}

Neutrophil disfunction, caused by a decreased production of effective radical oxygen species by myeloperoxidase (MPO) and NADPH oxidase within the neutrophil, may result in susceptibility to opportunistic fungal infections. In vitro, $\mathrm{MPO}$ produces $\mathrm{OCl}$, which kills bacteria and viruses. In the case of MPO deficiency, susceptibility to Candida albicans infection was observed ${ }^{1,2)}$. Furthermore, it was demonstrated that MPO knockout mice were primarily susceptible to $C$. albicans infection. With regards to NADPH oxidase deficiency, such a patient was found to have severe chronic granulomatous disease (CGD) due to Aspergillus infection. This deficiency may have resulted from a gene mutation and/or abnormality of the NADH oxidase components, particularly cytochrome $b_{558}$ (gp91 phox and $\mathrm{p} 22^{\text {phox }}$ ) in membrane and cytosol factors $\mathrm{p} 47^{\text {phox }}, \mathrm{p} 67^{\text {phox }}, \mathrm{p} 40^{\text {phox }}$ and others in neutrophil. Thus, irregular regulation of transcription factors for gene expression of phox molecules and MPO permits susceptibility to Aspergillus and Candida infections.

この論文は, 第45 回日本医真菌学会総会の “シンポジウム II : 難治性深在性真菌症一新しい観点からー” に扔いて発表されたものです。 